\title{
Early and early Middle Ordovician chitinozoans from the Baldone drill core, central Latvia
}

\author{
Jaak Nõlvak ${ }^{\mathrm{a}}$, Yan Liang ${ }^{\mathrm{b}}$ and Olle Hints ${ }^{\mathrm{a}^{*}}$ \\ ${ }^{a}$ Department of Geology, Tallinn University of Technology, Ehitajate tee 5, 19086 Tallinn, Estonia; jaak.nolvak@taltech.ee \\ ${ }^{\mathrm{b}}$ State Key Laboratory of Palaeobiology and Stratigraphy, Nanjing Institute of Geology and Palaeontology, Chinese Academy of \\ Sciences, Nanjing 210008, China \\ *Corresponding author, olle.hints@taltech.ee
}

Received 10 December 2021, accepted 3 February 2022, available online 1 March 2022

\begin{abstract}
Early and early Middle Ordovician chitinozoans are relatively poorly known in Baltoscandia, thus the understanding of the early diversification of the group, as well as its biostratigraphic utility, is limited. In this paper, we document the distribution of chitinozoans in the Floian and lower Darriwilian strata of the Baldone drill core from central Latvia, a region from where very limited data on chitinozoans have hitherto been available. The Baldone section hosts one of the thickest upper Lower to lower Middle Ordovician sequences in eastern Baltoscandia and is represented by $\mathrm{ca} 85 \mathrm{~m}$ of red-coloured, mottled and less commonly grey marls and limestones. Chitinozoans were collected from 20 samples, revealing altogether at least 13 genera and 35 species. The lowermost productive sample, attributed to the lower Floian, represents one of the oldest chitinozoan faunas from Baltica. The upper Floian and Dapingian redbeds are barren of chitinozoans, but the lower Darriwilian Šakyna and Baldone formations contain a rich and wellpreserved assemblage with range-through taxonomic diversity reaching up to 19 species per sample. The Baldone section provides new insights into the distribution of the regional biozonal species Cyathochitina regnelli, which is characteristic of the Kunda Regional Stage in Estonia and Sweden. Several other biostratigraphically significant species of Cyathochitina, Conochitina and Lagenochitina that are typical of other regions were also recovered. They suggest links with chitinozoan assemblages of other continents during the early Darriwilian. Based on the rich collection at hand, chitinozoan diversity estimates for early Darriwilian are increased, and four new chitinozoan species are described: Bursachitina baldonia, Conochitina ulsti, Eremochitina? procera and Sphaerochitina? latviensis.
\end{abstract}

Key words: Early and Middle Ordovician, Chitinozoa, Baltoscandia, Latvia, biostratigraphy.

\section{INTRODUCTION}

Chitinozoans are a common group of organic-walled marine microfossils in Ordovician to Devonian rocks (Eisenack 1931; Paris et al. 1999; Servais et al. 2013). They are widely used in biostratigraphy despite the fact that their biological origin has remained controversial (see Miller 1996; Paris \& Nõlvak 1999; Liang et al. 2019, 2020a for a review). In the Baltic region, Ordovician chitinozoans have been studied in the pioneering works of Alfred Eisenack since the 1930s (see Eisenack 1976 for references) and by many subsequent authors (e.g. Laufeld 1967; Obut 1973; Grahn 1980, 1982a, 1982b; Nõlvak 1980, 2010; Wrona 1980; Schallreuter 1981; Obut 1995; Tammekänd et al. 2010; Grahn \& Paris 2011; Hints et al. 2011, 2018; Nõlvak et al. 2019; Liang et al. 2022). These studies have resulted in some of the largest collections and distributional data sets worldwide. On the basis of the obtained data, regional biozonation has been established (Nõlvak \& Grahn 1993; Nõlvak et al. 2006), and the diversification history of the Ordovician Chitinozoa in Baltoscandia has been reconstructed (Kaljo et al. 1996; Paris et al. 2004; Achab \& Paris 2007; Hints et al. 2011, 2018). However, the knowledge on Baltic chitinozoans is not evenly distributed across the region and time scale. Notably, the Early and early Middle Ordovician strata, collectively known as the Öland Regional Series in Baltoscandia, have received relatively less attention thus far (see Nõlvak et al. 2019 for a review). This has resulted in a bias in our understanding of both the diversity and biogeographic patterns within Baltica, as well as globally. The biostratigraphic potential of chitinozoans has yet to be fully explored in these strata too. This knowledge gap is partly due to a preservation bias - chitinozoans are not 
present in red-coloured (oxidized) rocks, and in dolomitized or siliciclastic successions their occurrences are scattered and finds of rich assemblages are rare.

In the eastern part of the Baltoscandian Basin, Ölandian chitinozoans have been reported from the shallow shelf settings of northern Estonia (Grahn 1984; Hints \& Nõlvak 2006; Nõlvak et al. 2019). From deeper shelf environments, Ulst et al. (1982, p. 141) quoted some unpublished chitinozoan data from the Vergale-46 drill core of western Latvia. However, no first-hand taxonomic or distributional data sets have been previously published from the Ölandian succession of Latvia. During the screening of micropalaeontological samples from several subsurface sections, a rich chitinozoan assemblage was recovered from the Baldone-80 drill core of central Latvia (for brevity, Baldone drill core hereafter). This section hosts some of the thickest Ölandian packages in the East Baltic region, and it is stratigraphically more complete than the shallow shelf succession in the outcrop area in northern Estonia.

The aim of this study is to document the taxonomic composition and diversity of the Ölandian chitinozoan assemblage of central Latvia for the first time. Moreover, the new rich material allows for a discussion on the biostratigraphic and biogeographic aspects of the Early and early Middle Ordovician chitinozoans of Baltica and description of new species.

\section{GEOLOGICAL SETTINGS AND STRATIGRAPHY}

The Baltoscandian Basin covered large parts of Baltica during the Early and early Middle Ordovician Period.
Widespread carbonate sedimentation commenced in the basin during the late Early Ordovician. This was connected to the drift of Baltica into lower latitudes (Cocks \& Torsvik 2005, 2021), and supported by the onset of the Great Ordovician Biodiversification Event, which enhanced carbonate production by the shelly faunas. The Baltoscandian Basin is usually divided into broad facies zones (cf. Männil 1966), the so-called confacies belts of Jaanusson (1976, 1995), with proximal shallow shelf settings in northern Estonia (the North Estonian Confacies), deeper shelf environments in southern Estonia, Latvia, northern Lithuania and Sweden (the Central Baltoscandian Confacies) and distal slope facies further towards the west, where the Törnquist Ocean was present (Fig. 1).

The stratigraphic focus of this study is on the Öland Regional Series, which corresponds to an interval from the Tremadocian to lower Darriwilian, and embraces the Pakerort, Varangu, Hunneberg, Billingen, Volkhov and Kunda regional stages (Nõlvak et al. 2006, 2019). The Ölandian succession is generally very condensed all over Baltoscandia as the deposition took place in a sedimentstarved basin with a relatively small topographic differentiation (Männil 1966; Lindskog et al. 2020). In northern Estonia, the Öland Series is only few tens of metres thick, with the Tremadocian and Floian usually representing less than $10 \mathrm{~m}$ (Hints 2014a, 2014b). In the distal settings of central Latvia, the net sediment accumulation rate was higher and stratigraphic hiatuses were shorter, therefore the same sequence is more than $80 \mathrm{~m}$ thick there (Ulst et al. 1982).

The stratigraphic framework of the Lower and lower Middle Ordovician strata in Latvia is based on litho-

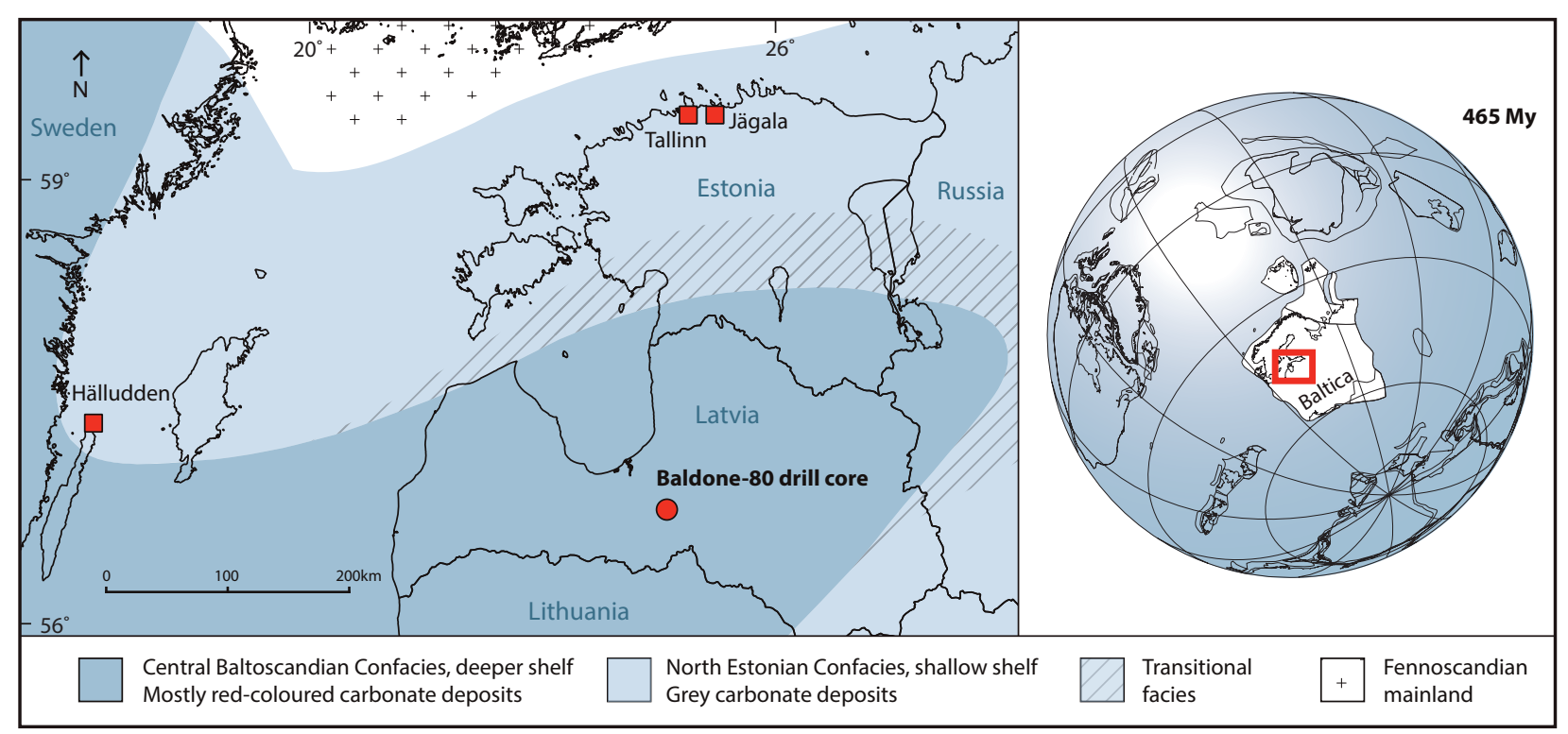

Fig. 1. Locality map and palaeogeography of the study area during early Darriwilian Kunda time. The configuration of the Baltoscandian palaeobasin is according to Männil (1966). 
stratigraphy, gamma-ray logs and the shelly fossil record, notably trilobites and ostracods (Ulst et al. 1982 and references therein). To some extent, conodonts have also been used, but there are no recent biostratigraphic studies comparable with the high-resolution data from Sweden (Bergström et al. 2011; Wu et al. 2017) and Estonia (Löfgren et al. 2005; Nõlvak et al. 2006; Viira 2011; Hints et al. 2012). Tracing both global or regional stage boundaries in Latvian sections is therefore complicated and awaits new studies on conodonts. The stage boundaries of the Floian, Dapingian and Darriwilian thus remain tentative at present. However, the conventional Baltic regional stages (Nõlvak et al. 2006) are referred to in the present study.

The thickness of the Öland Series in the Baldone core is $c a 84 \mathrm{~m}$. The succession contains sandstones of the Kallavere Formation (Pakerort Regional Stage), mostly red clays and marls of the Zebre Formation (Varangu, Hunneberg and Billingen regional stages) and red marls of the Kriukai Formation (mostly Volkhov Regional Stage). The last formation is overlain by reddish and greyish marls with rare limestone interbeds, attributable to the Šakyna Formation, and the Baldone Formation (both Kunda Regional Stage) mainly consisting of bioclastic, variably nodular limestones, with marly interbeds, red-coloured spots, and limonitic discontinuity surfaces in the topmost part. Both the Šakyna and Baldone formations contain rich chitinozoan assemblages that are described in this study. The Baldone Formation is in turn overlain by the red-coloured argillaceous limestones of the Segerstad Formation (Aseri Regional Stage), which is barren of organic-walled microfossils. The younger part of the Ordovician System is also well represented and fossiliferous in the Baldone drill core; however, its characterization is beyond the scope of this study.

\section{MATERIAL AND METHODS}

The chitinozoan material comes from samples collected from the Baldone section in 1972. Altogether 20 samples, varying from $\mathrm{ca} 150$ to $300 \mathrm{~g}$ in size, were studied. Whereas six of these were barren of organic-walled microfossils due to unfavourable preservation conditions and possibly insufficient sample size, the remaining samples yielded thousands of chitinozoan vesicles. Additionally, lingulates, conodonts, rare scolecodonts, graptolite fragments, acritarchs, and some rare groups such as the mazuelloids (see Aldridge \& Armstrong 1981) and the cryptic, organic-walled Vikisphaera kundana (Hints et al. 2021) were recorded.

Acid-resistant microfossils were extracted from carbonate samples using acetic or hydrochloric acid $(\mathrm{HCl})$. The siliciclastic samples from the lower part of the suc- cession were treated with $\mathrm{HCl}$ and hydrofluoric acid (HF). Samples from the clay-rich interbeds were disintegrated in water, with the addition of hydrogen peroxide. The residues were washed through a $45-$ or $63-\mu \mathrm{m}$ sieve to remove clay. Chitinozoans and other microfossils were then handpicked, glued to SEM stubs or stored in small plastic containers with glycerine. The specimens were observed under a Leica M205 stereo microscope, which was also used for measurements. All sample residues, microfossil preparations and figured specimens are deposited at the Department of Geology, Tallinn University of Technology (institutional abbreviation GIT).

\section{RESULTS AND DISCUSSION}

\section{Chitinozoan assemblages}

Altogether 35 chitinozoan species of 13 genera were identified in the Ölandian part of the Baldone section (Fig. 2, Table 1), following the chitinozoan classification of Paris et al. (1999). The oldest productive sample from the Zebre Formation contains only two species. Upsection, the number of species per sample reaches 13 in the lower part of the Baldone Formation, being slightly lower in the upper part of the formation and in the subjacent Šakyna Formation. The maximum recorded range-through species diversity of 19 is observed in the Baldone Formation. However, the red-coloured strata did not contain chitinozoans and a few other samples also turned out to be barren (M-13677 and M-13678; Fig. 2), probably due to unfavourable preservation conditions.

Taxonomically, the studied chitinozoan assemblage is broadly similar to those previously described from coeval strata of Estonia and Sweden (Nõlvak et al. 2019 and references therein). However, a number of taxa are identified from Baltica for the first time, including the four new species described in this study: Bursachitina baldonia, Conochitina ulsti, Eremochitina? procera and Sphaerochitina? latviensis. Nine species of Angochitina, Belonechitina, Conochitina, Euconochitina, Lagenochitina and Rhabdochitina are referred to using open nomenclature due to limited material and the need for further assessment of their variability and distribution, particularly in other localities in Latvia. All these species are illustrated in Figs 3-6 and included in the diversity counts.

\section{Biostratigraphy}

The assemblage includes one index species, Cyathochitina regnelli, of the regional chitinozoan biozonation (Nõlvak \& Grahn 1993; Nõlvak et al. 2006), and several other species that provide age constraints. The succession can be broadly divided into three units containing chitinozoans, 


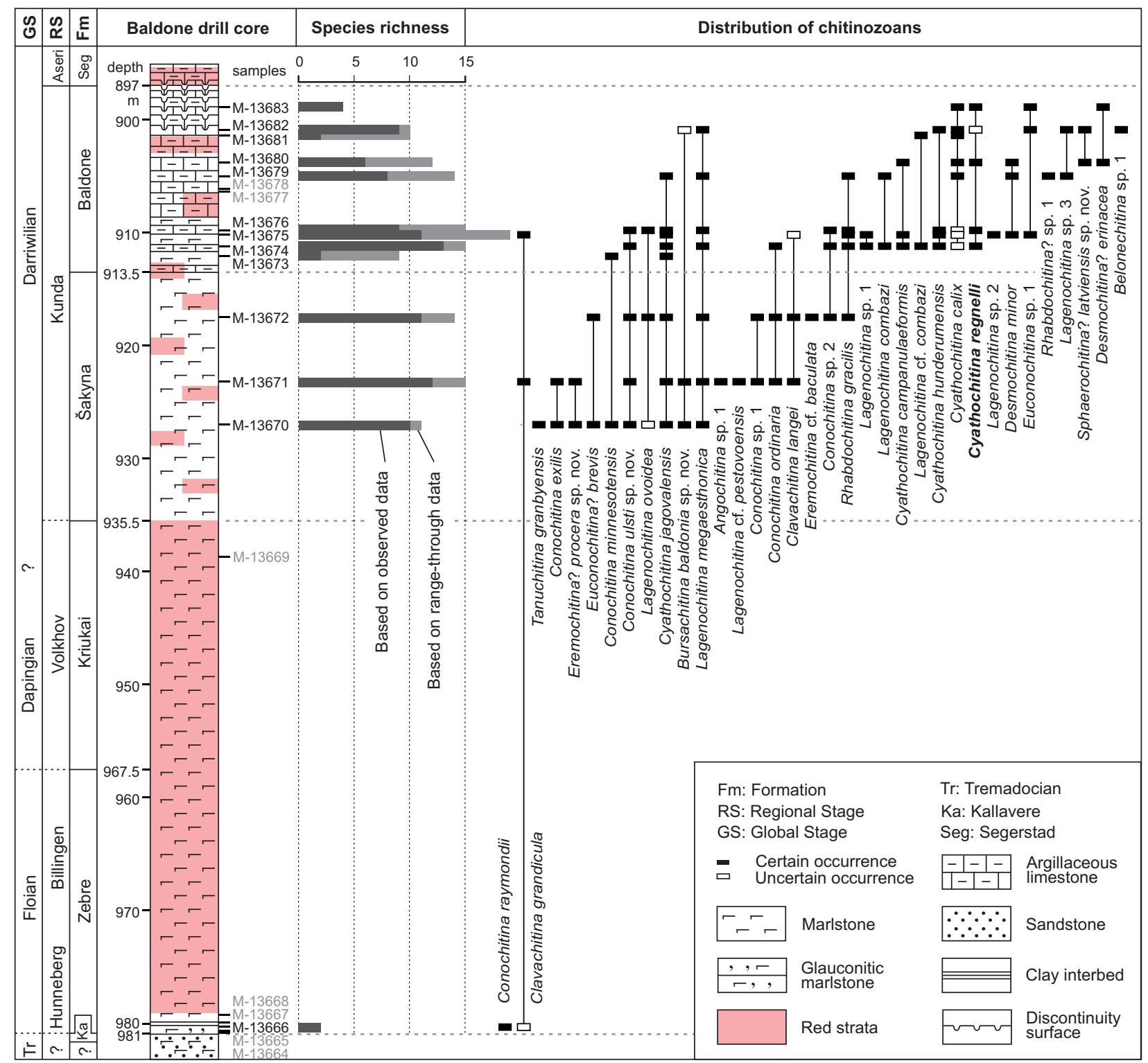

Fig. 2. Stratigraphic background and the distribution of chitinozoans in the Baldone drill core, central Latvia. Stratigraphy modified from Ulst et al. (1982). Grey sample numbers indicate barren samples.

that is the Zebre, Šakyna and Baldone formations, but also the barren intervals are briefly commented on.

The Zebre Formation (thickness $13.5 \mathrm{~m}$, interval $967.5-981.0 \mathrm{~m}$ ) is represented mostly by red-coloured marls; however, there is a $1.8 \mathrm{~m}$ interval (979.2-981.0 m) of greenish-grey marls containing glauconite grains and thin $(<5 \mathrm{~mm})$ brownish mudstone intercalations in the lowermost part of the formation. One of the five samples collected from this interval (each $\mathrm{ca} 200 \mathrm{~g}$ ) was productive for microfossils - in addition to rare graptolite fragments, flattened specimens of two chitinozoan species, Conochitina raymondii and Clavachitina grandicula were found.
Conochitina raymondii (Fig. 5Y-Z) is distinguished by its large vesicle, around $500-800 \mu \mathrm{m}$ in length, with a poorly differentiated flexure, and a chamber widening towards the flat base. The Baldone specimens constitute the first record of this species in Baltoscandia and provide some biostratigraphic information. Originally, C. raymondii was reported from the lower part of the lower Floian Lévis Formation in Quebec, Canada (Achab 1980), where it cooccurs with Clavachitina grandicula. Later, the species has been identified also from the lower Floian Cow Head Group in Newfoundland (Achab 1986), the uppermost Tremadocian Fenghsiang Formation in the Yichang area, 
J. Nõlvak et al.: Ordovician chitinozoans from Latvia

Table 1. List of chitinozoan species from the Lower and lower Middle Ordovician of the Baldone drill core, central Latvia. Occurrences are coded by '?' in case of uncertain identification

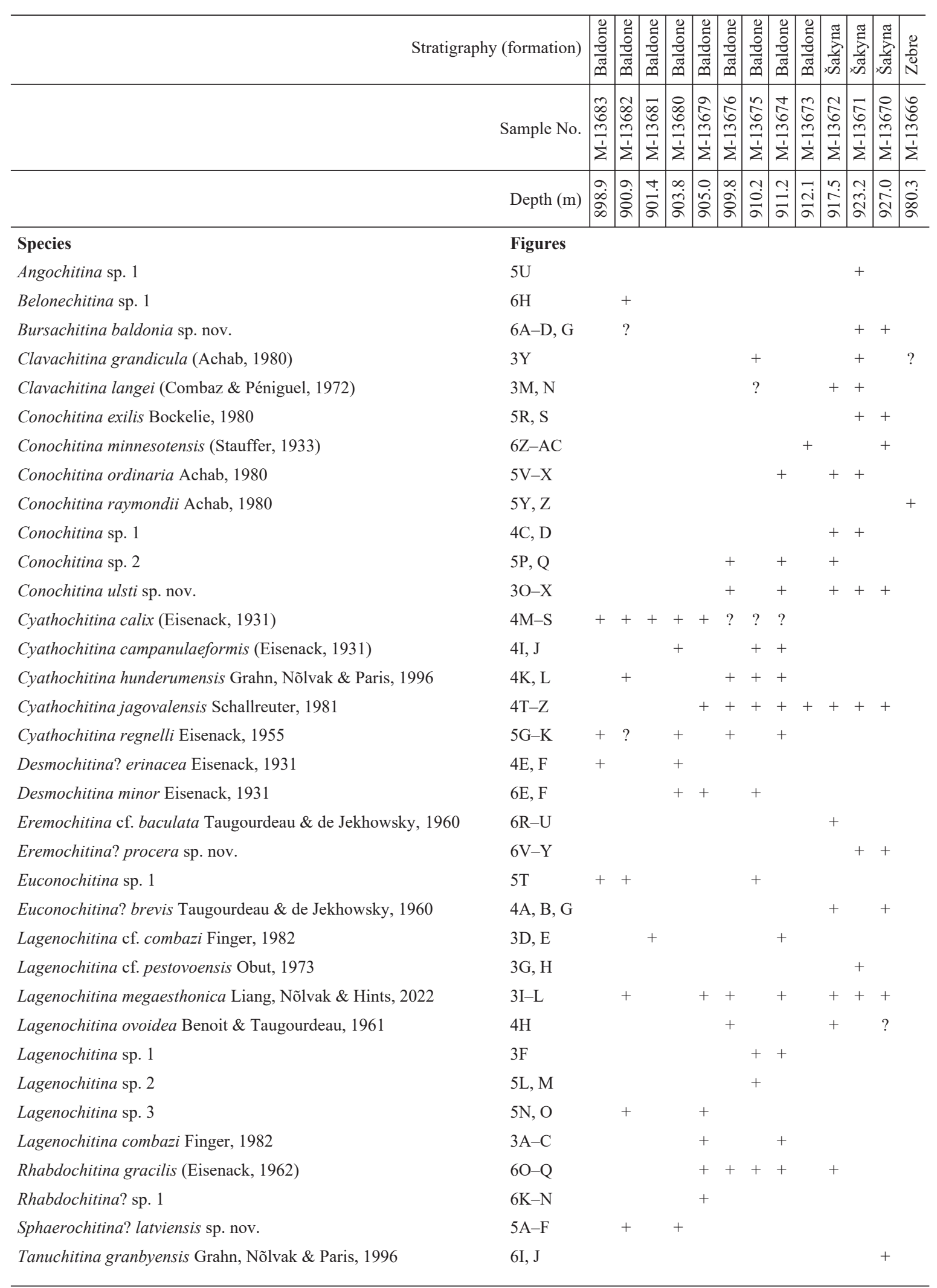



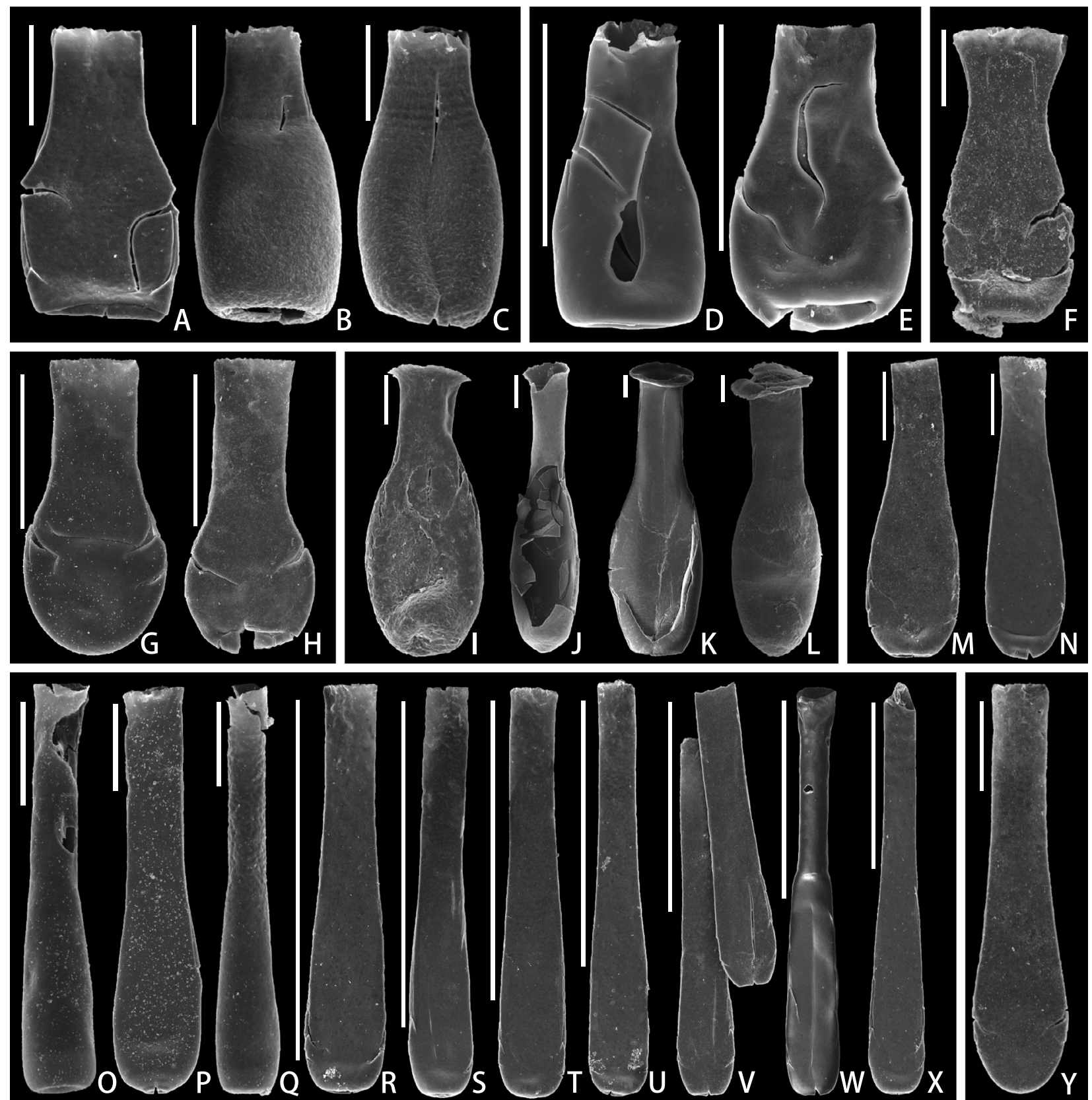

Fig. 3. SEM photos of chitinozoans from the Baldone drill core, central Latvia. The scale bar represents $100 \mu \mathrm{m}$, except in figures $\mathrm{R}-\mathrm{X}$ where it represents $500 \mu \mathrm{m}$. For sample positions and stratigraphy see Fig. 2. A-C, Lagenochitina combazi; D, E, Lagenochitina cf. combazi; F, Lagenochitina sp. 1; G, H, Lagenochitina cf. pestovoensis; I-L, Lagenochitina megaesthonica; M, N, Clavachitina langei; O-X, Conochitina ulsti sp. nov. (T, holotype); Y, Clavachitina grandicula. A, GIT 854-1, sample M-13674; B, GIT 854-2, sample M-13679; C, GIT 854-3, sample M-13674; D, GIT 854-4, sample M-13681; E, GIT 854-5, sample M-13674; F, GIT 854-6, sample M-13675; G, GIT 854-7, sample M-13671; H, GIT 854-8, sample M-13671; I, GIT 854-9, sample M-13674; J, GIT 854-10, sample M-13682; K, GIT 833-4, paratype of L. megaesthonica in Liang et al. (2021); L, GIT 854-11, sample M-13674; M, GIT 854-12, sample M-13671; N, GIT 854-13, sample M-13670; O, GIT 854-14, sample M-13675; P, GIT 854-15, sample M-13675; Q, GIT 854-16, sample M-13675; R, GIT 854-17, sample M-13670; S, GIT 854-18, sample M-13676; T, GIT 854-19, sample M-13670; U, GIT 854-20, sample M-13670; V, GIT 854-21, sample M-13671; W, GIT 854-22, sample M-13676; X, GIT 854-23, sample M-13670; Y, GIT 854-24, sample M-13671. 
South China (Zhang \& Chen 2009), the uppermost part of the Hunghuayuan Formation and in the lower part of the Dawan Formation, lower Floian, in Yichang, China (Chen et al. 2009). The specimens identified as C. raymondii from the uppermost Meitan Formation (latest Dapingian to earliest Darriwilian) at Tongzi, South China (Liang et al. 2018) share a similar outline to the holotype but have a somewhat smaller vesicle (length $c a 400-500 \mu \mathrm{m}$ ) and more straight flanks.

Achab (1989) established the C. raymondiiLagenochitina esthonica Assemblage Biozone just above the globally recognized Euconochitina symmetrica Zone, the base of which has long been taken as coinciding with the base of the Paratetragraptus approximatus graptolite Zone and the base of the Floian Stage (Achab 1989; Paris et al. 2004). However, the age of this zone was recently revised by Achab \& Maletz (2021) on the basis of new graptolite data from Laurentia, suggesting that the E. symmetrica chitinozoan assemblage is older than the base of the $P$. approximatus Zone. It characterizes the upper Tremadocian Sagenograptus murrayi graptolite Zone, but its upper part could reach the Floian Stage. Euconochitina symmetrica has been recovered also from the upper Tremadocian of South China (Wang et al. 2013; Liang et al. 2017), Morocco (Nowak et al. 2016) and northern England (Amberg et al. 2017). The FAD of $C$. raymondii within the $P$. approximatus Zone in Canada suggests that the basal part of the Zebre Formation in the Baldone drill core is likely of early Floian age, corresponding to the upper part of the Hunneberg Regional Stage. It is thus younger than the supposedly late Tremadocian assemblages from the Jägala and Tallinn sections in northern Estonia (Hints \& Nõlvak 2006; Nõlvak et al. 2019).

Marly facies continue in the Kriukai Formation (32 m, interval 935.5-967.5 m, according to Ulst et al. 1982). Red marls are barren of organic-walled microfossils (for instance, the sample at $938.8 \mathrm{~m}$ depth in Fig. 2). Fragmentary macrofossils such as trilobites and brachiopods are found in these beds, but conodonts need to be studied for higher biostratigraphic resolution. Data from other sections suggest that the base of the Dapingian lies close to the base of the Kriukai Formation (Viira 2011).

The Šakyna Formation (22 m, interval 913.5-935.5 m, according to Ulst et al. 1982) is represented mainly by grey marls with irregular reddish patches or interlayers, often only a few centimetres thick. The formation has been correlated with a gap in northern Estonia (Nõlvak 1997, table 7; Ainsaar et al. 2020) and eastern Latvia (Ulst et al. 1982, p. 170), and with the upper Sillaoru Formation in central and northeastern Estonia (e.g. Põldsaar et al. 2019). In southern Sweden, the Šakyna Formation can be correlated with the grey Täljsten bed within the Holen Limestone (Ainsaar et al. 2020). Conodont biostratigraphy places the Täljsten interval into the Lenodus variabilis Zone, lower Darriwilian, Kunda Regional Stage (Lindskog et al. 2014, 2017), and this is also supported by conodont data from southern Estonia and Russia (Viira 2011). Originally, the Kunda age for this interval was proposed based on rare trilobite finds (Männil 1963, 1966; Ulst et al. 1982).

Three productive samples from the Šakyna Formation in the Baldone section revealed a diverse and characteristic chitinozoan assemblage, unknown from other Baltic localities so far, notably due to the predominance of barren redbeds in deeper shelf settings and a gap in shallow shelf regions (for instance, in the Jägala section in northern Estonia studied by Nõlvak et al. 2019). The Šakyna chitinozoan assemblage contains 11 genera and 19 species (Fig. 2), including Conochitina minnesotensis, C. exilis, C. ordinaria, Clavachitina langei, C. grandicula, Cyathochitina jagovalensis, Eremochitina cf. baculata, Euconochitina? brevis, Lagenochitina ovoidea, L. megaesthonica, L. cf. pestovoensis, Rhabdochitina gracilis, Tanuchitina granbyensis, and three new species: Eremochitina? procera, Conochitina ulsti and Bursachitina baldonia.

A characteristic feature of this interval is the occurrence of Eremochitina, which is generally rare in Baltoscandia and previously recorded only form the preKunda strata (Nõlvak \& Grahn 1993; Hints \& Nõlvak 2006). In the Baldone section, the genus is represented by Eremochitina cf. baculata and the new species E.? procera. In the Tallinn section, highly variable specimens of this genus were found from the latest Tremadocian strata (Hints \& Nõlvak 2006). In Gondwanan sections, this genus is known only from the lower part of the Ordovician (Paris at al. 1999).

Another noteworthy taxon in the Šakyna assemblage is Bursachitina baldonia. To our knowledge, this is the oldest record of the genus Bursachitina in Baltica. Moreover, Clavachitina langei (Fig. 3M-N) is reported from Baltoscandia for the first time. It is a rare species in the Šakyna Formation and probably ranges into the lower Baldone Formation. It has previously been reported from the upper Floian to Darriwilian of western Australia (Combaz \& Peniguel 1972; Quintavalle \& Playford 2006) and North America (Achab 1986; Asselin et al. 2004), middle Floian of northwestern Argentina (de la Puente \& Rubinstein 2013), upper Darriwilian of Tarim (Geng et al. 2000) and middle Floian to lower Darriwilian of South China (Wang \& Chen 1994; Tang et al. 2007; Chen et al. 2009; Liang et al. 2018). The Euconochitina brevisLagenochitina (= Clavachitina) langei Biozone was established for the middle and upper part of the Canadian Regional Series, corresponding to the upper Floian to upper Dapingian in Quebec and western Newfoundland (Achab 1989). Asselin et al. (2004) have drawn the upper 
boundary of this biozone in the middle Dapingian. The Clavachitina langei Biozone has been used for the middle Floian to earliest Dapingian in South China (Chen et al. 2009); however, Liang \& Tang (2016) showed that C. langei ranges into the lower Darriwilian in the region.
This is the case also in the Baldone section, where C. langei is distributed in the lower Darriwilian.

Cyathochitina jagovalensis (Fig. 4T-Z) was erected as a subspecies of Cyathochitina calix by Schallreuter (1981), distinguished by having a smaller and stouter

vesicle with a more pronounced shoulder (Eisenack 1962, pl. 14, fig. 3 as C. calix and fig. 4 as C. jagovalensis); however, transitional forms may occur. In the Šakyna Formation and lower part of the Baldone Formation, characteristic C. jagovalensis (Fig. 4U-Z) occurs almost continuously, but higher in the succession, transitional forms between $C$. jagovalensis and $C$. calix appear (Fig. 4M, N, T) and distinction between the two species becomes difficult. A similar succession was observed in the Jägala section of Estonia, where C. jagovalensis appears in the Toila Formation, uppermost Dapingian, followed closely by C. calix (Nõlvak et al. 2019). Cyathochitina jagovalensis has also been reported from the mid-Darriwilian Kandle and Väo formations of northern Estonia (Tammekänd et al. 2010; Hints et al. 2012; Wang et al. 2021), the Furudal and Dreimani formations, upper Darriwilian to lower Sandbian, of western Latvia (Goldman et al. 2015) and the lower Widowo Formation, lower and middle Darriwilian, of Poland (Modliński et al. 2002).

Conochitina minnesotensis is found in two samples from the Šakyna and Baldone formations (Fig. 2), being represented by peculiar, curved specimens (Fig. 6AB, $\mathrm{AC})$. It has a long stratigraphic range in Baltoscandia and is common, but rarely abundant, in Darriwilian to Katian strata (e.g. Saadre et al. 2004; Grahn \& Nõlvak 2007a, 2007b, 2010; Goldman et al. 2015). Its oldest record comes from the Dapingian/Darriwilian Lanna Limestone in Sweden (Grahn \& Nõlvak 2007a). Elsewhere it is reported from the Late Ordovician of Oklahoma (Goldman et al. 2007), Mohawkian of Minnesota, USA (Stauffer 1933), and Arenigian to Llandeilian of the Canning Basin, Australia (Combaz \& Peniguel 1972). Another stratigraphically significant species in the Šakyna Formation is Tanuchitina granbyensis, a species first described from the lower Darriwilian of Sweden (Grahn et al. 1996).

In northern Estonia, the lower boundary of the Kunda Stage coincides with the base of the Cyathochitina regnelli Biozone. In several stratigraphic schemes, such as that by Nõlvak (1997), the Šakyna Formation has been regarded as belonging to the $C$. regnelli Zone, which is supported by scattered data from southern Estonia (Põldvere et al. 1998). However, in the Baldone section the nominal species appears in the Baldone Formation, suggesting that the age of the base of the $C$. regnelli Zone may need reconsidering when data from additional sections together with conodont biostratigraphy become available.

The Baldone Formation (16.5 m, interval 897.0$913.5 \mathrm{~m}$, according to Ulst et al. 1982) has its stratotype in the Baldone section. The formation yields a relatively rich assemblage of chitinozoans comprising 23 species, 15 of which appear near its lower boundary (Fig. 2). These include, for example, Sphaerochitina? latviensis, abundant Cyathochitina campanulaeformis, C. hunderumensis and the zonal index species $C$. regnelli (Fig. 5G-K). This index species ranges through the Baldone Formation in the Baldone section and is known from many localities across Baltoscandia. Cyathochitina regnelli was first reported from the 'Expansus Limestone' (= lower Holen Limestone, lower Kunda Stage) at Fjäcka, south-central Sweden (Eisenack 1955) and is known from many Estonian sections, occurring below the FAD of Laufeldochitina striata (Nõlvak 2010 and references therein).

Cyathochitina regnelli is accompanied by Cyathochitina hunderumensis (Fig. 4K-L) in the Baldone core. A very similar distribution pattern is followed in the Jägala section, northern Estonia, where both species occur together and are characteristic of the Kunda Regional Stage (Nõlvak et al. 2019, fig. 3). The type material of C. hunderumensis comes from the lower Kunda Regional Stage in the Granby crater, southern Sweden (Grahn et al. 1996). Cyathochitina hunderumensis has been reported also from the lower Darriwilian of southern Norway (Grahn \& Nõlvak 2007b), in northeastern Poland (Modliński et al. 2002) and western Estonia (Nõlvak 2010; Hints et al. 2014), sometimes below C. regnelli. In the Tartu 453 core, southern Estonia, both $C$. hunderumensis and $C$. regnelli occur in the Šakyna Formation (Põldvere et al. 1998).

\section{Notes on diversity patterns and biogeography}

The early diversification of chitinozoans in the Baltic region has been discussed in a number of publications, for instance, Kaljo et al. (1996), Paris et al. (2004) and Hints et al. (2010, 2011, 2018). More recently, Nõlvak et al. (2019) studied chitinozoans from the Jägala section in

Fig. 4. SEM photos of chitinozoans from the Baldone drill core, central Latvia. The scale bar represents $100 \mu$ m. For sample positions and stratigraphy see Fig. 2; the authors of species are listed in Table 1. A, B, G, Euconochitina? brevis; C, D, Conochitina sp. 1; E, F, Desmochitina? erinacea; H, Lagenochitina ovoidea; I, J, Cyathochitina campanulaeformis; K, L, Cyathochitina hunderumensis; M-S, Cyathochitina calix; T-Z, Cyathochitina jagovalensis. A, GIT 854-25, sample M-13672; B, GIT 854-26, sample M-13672; C, GIT 85427, sample M-13672; D, GIT 854-28, sample M-13672; E, GIT 854-29, sample M-13683; F, GIT 854-30, sample M-13680; G, GIT 854-31, sample M-13670; H, GIT 854-32, sample M-13676; I, GIT 854-33, sample M-13674; J, GIT 854-34, sample M-13675; K, GIT 854-35, sample M-13675; L, GIT 854-36, sample M-13674; M, GIT 854-37, sample M-13680; N, GIT 854-38, sample M-13679; O, GIT 854-39, sample M-13679; P, GIT 854-40, sample M-13679; Q, GIT 854-41, sample M-13679; R, GIT 854-42, sample M-13679; S, GIT 854-43, sample M-13682; T, GIT 854-44, sample M-13675; U, GIT 854-45, sample M-13675; V, GIT 854-46, sample M-13676; W, GIT 854-47, sample M-13671; X, GIT 854-48, sample M-13671; Y, GIT 854-49, sample M-13679; Z, GIT 854-50, sample M-13676. 
northern Estonia and showed that the regional diversification was more gradual in the Dapingian than previously thought. The northern Estonian composite based on the Jägala and Tallinn sections also illustrated a diversity peak in the late Tremadocian, followed by a decline in the Floian (Nõlvak et al. 2019). A single productive sample from the Zebre Formation in the Baldone section adds two species to the Floian species rich-
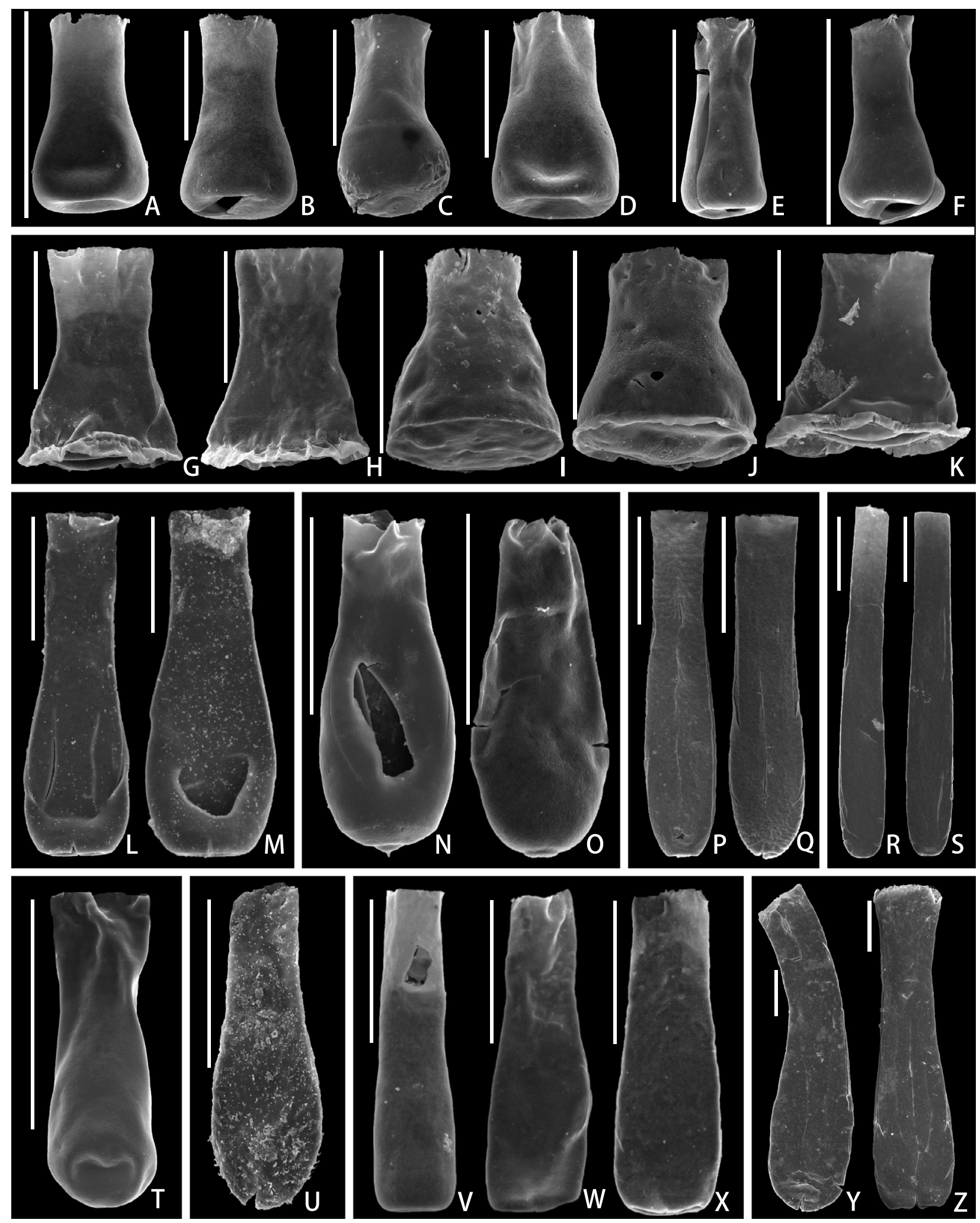
ness, most likely corresponding to the time slice ' $2 \mathrm{a}$ ' of Paris et al. (2004) and stage slice 'Fl1' of Bergström et al. (2009). This elevates Floian diversity estimates for the Baltic region slightly but does not fill the 'Floian chitinozoan diversity gap'. It remains to be tested if this gap marks a true regional faunal crisis or represents preservation and/or study bias.

Due to barren redbeds, the Baldone section does not contribute to a better understanding of the Dapingian diversity, and the taxa reported by Nõlvak et al. (2019) were not recorded in this section. However, the assemblage from the Šakyna Formation, which most likely corresponds to the early Darriwilian time slice ' $4 a$ ', adds a minimum of five, but possibly up to 11 species to those reported from northern Estonia by Nõlvak et al. (2019). The Baldone Formation, tentatively correlated with the time slice ' $4 b$ ', also adds several species to the previous compilation. Collectively these new data suggest notably higher taxonomic richness of early Darriwilian chitinozoans in eastern Baltoscandia, clearly exceeding the regional estimates of previous studies.

The diverse Baldone chitinozoan assemblage contains several species that were previously unknown in Baltoscandia, but occur in coeval assemblages of North Gondwana, Laurentia and China (e.g. Conochitina raymondii, Clavachitina langei). This indicates closer biogeographic relationships with other palaeocontinents during the early phase of the development of the group in Baltica than previously thought. Within Baltoscandia, the Baldone assemblage can be compared with the scattered records from similar environmental settings within the basin in southern Sweden and Norway (Grahn 1980; Grahn \& Nõlvak 2007a, 2007b, 2010). For instance, in the Hälludden section, northern Öland (Fig. 1), a rather similar assemblage is reported from the lower Darriwilian containing Cyathochitina regnelli, C. calix, C. campanulaeformis, C. hunderumensis, Conochitina minnesotensis, Lagenochitina megaesthonica, Lagenochitina ovoidea (described as Conochitina primitiva by Grahn 1980, fig. 12G, H) and Rhabdochitina gracilis (Eisenack 1972; Grahn 1980, 1982b; Grahn \& Nõlvak 2010, text-fig. 16). However, whereas species of Desmochitina are more diverse in Sweden than in the Baldone section, several species of Conochitina, Eremochitina and Lagenochitina found in the Baldone assemblage seem to be absent or less common in Sweden. A relatively low diversity is characteristic of the contemporaneous chitinozoan assemblages recovered from the Grötlingbo borehole, Gotland Island (Grahn \& Nõlvak 2010, text-fig. 24). Overall, the less diverse Swedish early Darriwilian chitinozoan assemblages may partly be due to smaller average sample sizes.

\section{SYSTEMATIC PALAEONTOLOGY}

The systematic framework and terminology are used according to Paris et al. (1999). The following main parameters are adopted in this study (note that we use an asterisk to stress that vesicle flattening is corrected): vesicle length (L), chamber diameter after correction $(\mathrm{Dp} *)$, neck diameter after correction (Dpn*), and ratios of the vesicle length/width (L/Dp*), neck length/vesicle length $(\mathrm{Ln} / \mathrm{L})$ and corrected neck diameter/chamber diameter $\left(\mathrm{Dpn} * / \mathrm{Dp}^{*}\right)$. The correction factor of the compressed vesicle follows Paris et al. (2015), with coefficients of 0.8 and 0.7 for the chamber and neck, respectively.

CHITINOZOA Eisenack, 1931

Order PROSOMATIFERA Eisenack, 1972

Family CONOCHITINIDAE Eisenack, 1931, emend. Paris, 1981

Subfamily CONOCHITININAE Paris, 1981

Genus Conochitina Eisenack, 1931, emend. Paris et al., 1999

Conochitina ulsti sp. nov.

Figure 3O-X

Etymology. Named in honour of Dr Rita Ulst, an expert on Ordovician geology of Latvia.

Holotype. Specimen GIT 854-19 (Fig. 3T) from the sample M-13670, depth $927.0 \mathrm{~m}$.

Type locality. Baldone drill core, central Latvia.

Type horizon. Šakyna Formation, Kunda Regional Stage, lower Darriwilian.

Fig. 5. SEM photos of chitinozoans from the Baldone drill core, central Latvia. The scale bar represents $100 \mu \mathrm{m}$ in all images except in figures R and S, where it corresponds to $200 \mu \mathrm{m}$, and in figures B-D where it represents $50 \mu \mathrm{m}$. For sample positions and stratigraphy see Fig. 2; authors of species are listed in Table 1. A-F, Sphaerochitina? latviensis sp. nov. (C, holotype); G-K, Cyathochitina regnelli; L, M, Lagenochitina sp. 2; N, O, Lagenochitina sp. 3; P, Q, Conochitina sp. 2; R, S, Conochitina exilis; T, Euconochitina sp. 1; U, Angochitina sp. 1; V-X, Conochitina ordinaria; Y, Z, Conochitina raymondii. A, GIT 854-51, sample M-13680; B, GIT 854-52, sample M-13680; C, GIT 854-53, sample M-13680; D, GIT 854-54, sample M-13680; E, GIT 854-55, sample M-13680; F, GIT 854-56, sample M-13680; G, GIT 854-57, sample M-13674; H, GIT 854-58, sample M-13674; I, GIT 854-59, sample M-13680; J, GIT 854-60, sample M-13682; K, GIT 854-61, sample M-13674; L, GIT 854-62, sample M-13675; M, GIT 854-63, sample M-13675; N, GIT 854-64, sample M-13682; O, GIT 854-65, sample M-13679; P, GIT 854-66, sample M-13676; Q, GIT 854-67, sample M-13676; R, GIT 854-68, sample M-13672; S, GIT 854-69, sample M-13672; T, GIT 854-70, sample M-13682; U, GIT 854-71, sample M-13671; V, GIT 854-72, sample M-13674; W, GIT 854-73, sample M-13674; X, GIT 854-74, sample M-13674; Y, GIT 854-75, sample M-13666; Z, GIT 854-76, sample M-13666. 
Diagnosis. Large to huge Conochitina with an average test length around $700 \mu \mathrm{m}$ and distinguished by its slim subcylindrical test.

Material. 160 specimens from the Šakyna and Baldone formations, samples M-13670 to M-13676.
Description. Vesicle slender and large, ranging from 397 to $1230 \mu \mathrm{m}$ in length, with a mean value of $709 \mu \mathrm{m}$ based on 20 specimens (Table 2). Flexure generally broad and sometimes distinct due to exceptional preservation (Fig. 3Q, W). Neck cylindrical, taking $1 / 3$ to $3 / 5$ of the vesicle in length and $1 / 2$ to $2 / 3$ of the chamber in diameter.
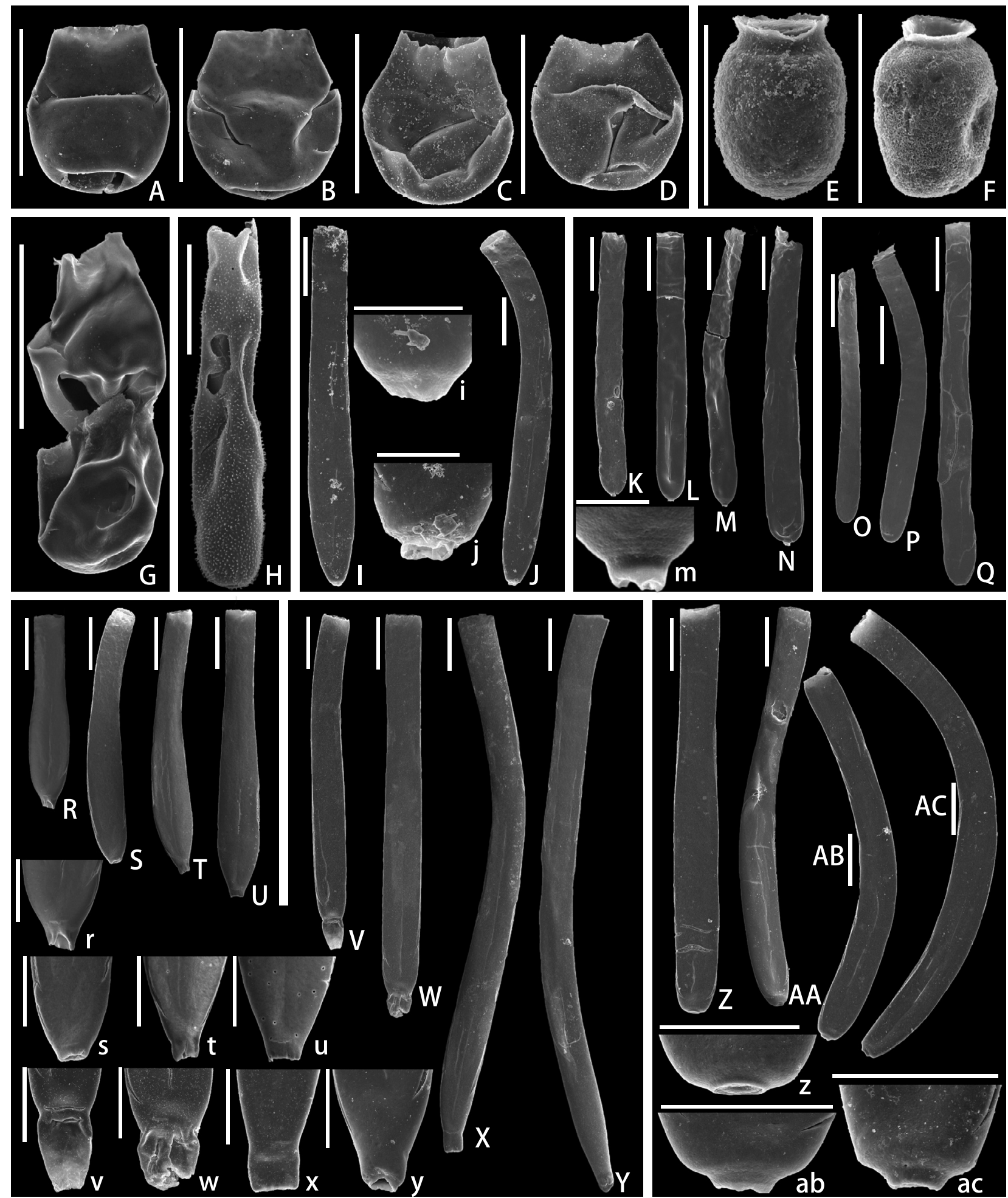
Table 2. Dimensions of Conochitina ulsti sp. nov. based on 20 specimens two of which are three-dimensionally preserved. $\mathrm{L}=$ vesicle length, $\mathrm{Ln}=$ neck length, $\mathrm{Dp}=$ chamber diameter, $\mathrm{Dpn}=$ neck diameter. Asterisk marks the application of the correction factors of 0.8 and 0.7 to the chamber and neck, respectively

\begin{tabular}{|c|c|c|c|c|c|c|c|c|c|}
\hline \multirow[t]{2}{*}{$n=20$} & $\mathrm{~L}$ & $\mathrm{Ln}$ & $\mathrm{Dp}$ & Dp* & Dpn & Dpn* & \multirow[t]{2}{*}{$\mathrm{L} / \mathrm{Dp} *$} & \multirow[t]{2}{*}{$\mathrm{Ln} / \mathrm{L}$} & \multirow[t]{2}{*}{$\mathrm{Dpn} * / \mathrm{Dp}^{*}$} \\
\hline & \multicolumn{6}{|c|}{$\mu \mathrm{m}$} & & & \\
\hline Minimum & 397 & 190 & 70 & 70 & 0 & 44 & 5.24 & 0.35 & 0.48 \\
\hline Maximum & 1230 & 508 & 170 & 136 & 100 & 75 & 10.51 & 0.59 & 0.68 \\
\hline Average & 706 & 304 & 113 & 93 & 66 & 53 & 7.49 & 0.44 & 0.58 \\
\hline Holotype & 690 & 270 & 114 & 91 & 78 & 55 & 7.57 & 0.39 & 0.60 \\
\hline
\end{tabular}

Collar usually slightly flared. Chamber subcylindrical with a maximum diameter located at the lower part of the chamber, where the rounded base margin begins. Flanks straight, base flat and sometimes with a scar. In the lower part of its range, the chamber is clearly lustreless verrucate under light microscope, compared with glabrous or sheen neck of the vesicle, especially in sample M-13670.

Remarks. Conochitina ulsti sp. nov. can be distinguished from other chitinozoans by its slim claviform vesicle. Conochitina grandicula also shares a long and slim vesicle, around $800 \mu \mathrm{m}$ in length, but the chamber is more like an elongated oval with an ogival base. Conochitina kryos Bockelie, 1980 shares a similar vesicle outline with C.ulsti, but is smaller (around $450 \mu \mathrm{m}$ ) and the neck takes a smaller proportion of the vesicle. The holotype of Conochitina clavaherculi Eisenack, 1959, with a vesicle length of ca $660 \mu \mathrm{m}$, also resembles $C$. ulsti in neck and chamber morphology but carries a more distinct flexure and is slimmer than C.ulsti. Conochitina platifundis Obut, 1995 also has a large vesicle, 853-1173 $\mu \mathrm{m}$ long, but differs from $C$. ulsti in having a truncate base and an elongated ovoid-like chamber. Conochitina raymondii, reported from the type locality in Quebec, ranges from 500 to $800 \mu \mathrm{m}$ in length and shares a cylindrical neck and conical to subcylindrical chamber, but the chamber is swollen in its lowermost part. Both Conochitina exilis Bockelie, 1980 and Conochitina incerta Eisenack, 1962 have an almost cylindrical vesicle $c a$ 400-500 $\mu \mathrm{m}$ long, and $C$. incerta has a sharp margin. Clavachitina langei also resembles $C$. ulsti to some extent but has a relatively short neck and swollen chamber.

Occurrence. Šakyna and Baldone formations, Darriwilian of Latvia.

Subfamily EREMOCHITININAE Paris, 1981

Genus Eremochitina Taugourdeau \& de Jekhowsky, 1960

Eremochitina? procera sp. nov.

Figure 6V-Y

Etymology. Latin 'procerus', meaning tall or long and referring to the extremely long vesicle.

Holotype. Specimen GIT 854-99 (Fig. 6W) from sample M-13671, depth $923.2 \mathrm{~m}$.

Type locality. Baldone drill core, central Latvia.

Type horizon. Šakyna Formation, Kunda Regional Stage, lower Darriwilian.

Diagnosis. Extremely long chitinozoan with a characteristic long and wide membrane.

Material. 49 specimens from the Šakyna Formation, samples M-13670 and M-13671.

Description. Vesicle extraordinarily long and slim, ranging from 1008 to $2237 \mu \mathrm{m}$ in length and having a relatively stable width, with a maximum diameter after correction ca $74 \mu \mathrm{m}$ (Table 3). The vesicle is almost

Fig. 6. SEM photos of chitinozoans from the Baldone drill core, central Latvia. The scale bar represents $100 \mu \mathrm{m}(\mathrm{A}-\mathrm{H}, \mathrm{r}-\mathrm{ac}), 200 \mu \mathrm{m}$ (I-AC), $50 \mu \mathrm{m}(\mathrm{i}, \mathrm{j})$ and $25 \mu \mathrm{m}(\mathrm{m})$. For sample positions and stratigraphy see Fig. 2; authors of species are listed in Table 1. A-D, G, Bursachitina baldonia sp. nov. (B, holotype); E, F, Desmochitina minor; H, Belonechitina sp. 1; I, J, Tanuchitina granbyensis; K-N, Rhabdochitina? sp. 1; O-Q, Rhabdochitina gracilis; R-U, Eremochitina cf. baculata; V-Y, Eremochitina? procera sp. nov. (W, holotype); Z-AC, Conochitina minnesotensis. A, GIT 854-77, sample M-13670; B, GIT 854-78, sample M-13670; C, GIT 854-79, sample M-13671; D, GIT 854-80, sample M-13671; E, GIT 854-81, sample M-13675; F, GIT 854-82, sample M-13680; G, GIT 854-83, sample M-13682; H, GIT 854-84, sample M-13682; I, GIT 854-85, sample M-13670; J, GIT 854-86, sample M-13670; K, GIT 854-87, sample M-13679; L, GIT 854-88, sample M-13679; M, GIT 854-89, sample M-13679; N, GIT 854-90, sample M-13679; O, GIT 854-91, sample M-13676; P, GIT 854-92, sample M-13674; Q, GIT 854-93, sample M-13674; R, GIT 854-94, sample M-13672; S, GIT 854-95, sample M-13672; T, GIT 854-96, sample M-13672; U, GIT 854-97, sample M-13672; V, GIT 854-98, sample M-13671; W, GIT 854-99, sample M-13671; X, GIT 854-100, sample M-13671; Y, GIT 854-101, sample M-13671; Z, GIT 854-102, sample M-13670; AA, GIT 854-103, sample M-13670; AB, GIT 854-104, sample M-13670; AC, GIT 854-105, sample M-13670. 
Table 3. Dimensions of nine flattened specimens of Eremochitina? procera sp. nov. $\mathrm{L}=$ vesicle length, $\mathrm{Lm}=$ tubular membrane length, $\mathrm{Dp}=$ chamber diameter, $\mathrm{Dpn}=$ the narrowest neck diameter. Asterisk marks the application of the correction factors of 0.8 and 0.7 to the chamber and neck, respectively

\begin{tabular}{|c|c|c|c|c|c|c|c|c|c|c|}
\hline \multirow[t]{2}{*}{$n=9$} & $\mathrm{~L}$ & $\mathrm{Lm}$ & $\mathrm{Dp}$ & $\mathrm{Dp}^{*}$ & Dpn & Dpn* & \multirow[t]{2}{*}{$\mathrm{L} / \mathrm{Dp}^{*}$} & \multirow[t]{2}{*}{$\mathrm{Lm} / \mathrm{L}$} & \multirow[t]{2}{*}{$\mathrm{Dpn} / \mathrm{Dp}$} & \multirow[t]{2}{*}{$\mathrm{Dpn} * / \mathrm{Dp}^{*}$} \\
\hline & \multicolumn{6}{|c|}{$\mu \mathrm{m}$} & & & & \\
\hline Minimum & 1008 & 53 & 125 & 70 & 107 & 47 & 14.40 & 0.03 & 0.78 & 0.67 \\
\hline Maximum & 2237 & 113 & 164 & 78 & 133 & 55 & 28.68 & 0.09 & 1.00 & 0.71 \\
\hline Average & 1580 & 76 & 144 & 74 & 123 & 51 & 21.17 & 0.05 & 0.86 & 0.69 \\
\hline Holotype & 1568 & 93 & 147 & 74 & 129 & 51 & 21.18 & 0.06 & 0.88 & 0.69 \\
\hline
\end{tabular}

cylindrical; the ratio of the narrowest diameter to maximum diameter $(\mathrm{Dpn} / \mathrm{Dp})$ ranges from 0.78 to 1.00 before correction, being $\mathrm{ca} 0.7$ when the correction factors are applied. Flexure very broad and it is hard to distinguish the neck and chamber. Flank straight and so is the aperture. Base margin rounded to inconspicuous. A long membrane (broad tubular copula) 53 to $113 \mu \mathrm{m}$ in length occurs at the base. The morphology of the membrane varies significantly; from being a straight tube as shown in Fig. 6X, a carina-like membrane as in Fig. 6W, to a tapering membrane as in Fig. 6V. The vesicle wall is smooth and relatively thick.

Remarks. This species is distinguished from all other chitinozoan species by its extremely long and cylindrical test with a characteristic, long membrane structure on the base. In some specimens the membrane looks like a copula (Fig. 6X-Y) of Eremochitina, or a carina-like structure of Tanuchitina (Fig. 6W). It also resembles a sleeve-like morphology of Velatachitina. Here we tentatively assign the species to Eremochitina because the relatively long and wide membrane has also been observed in Eremochitina baculata Taugourdeau \& de Jekhowsky, 1960.

Eremochitina? procera differs from E. baculata in its almost cylindrical and very long vesicle, while the latter has a more claviform and shorter chamber. Some specimens of Eremochitina sp. A. aff. baculata illustrated by Hints \& Nõlvak (2006, pl. 4, figs 2, 4) also have an almost cylindrical test but with a relatively obvious flexure and smaller size, always being shorter than $1000 \mu \mathrm{m}$.
Occurrence. Šakyna and Baldone formations, Darriwilian of Latvia.

Family LAGENOCHITINIDAE Eisenack, 1931, emend. Paris, 1981

Subfamily LAGENOCHITININAE Paris, 1981

Genus Sphaerochitina Eisenack, 1955, emend. Paris et al., 1999

Sphaerochitina? latviensis sp. nov. Figure $5 \mathrm{~A}-\mathrm{F}$

Etymology. Named after Latvia, the country of the type locality.

Holotype. Specimen GIT 854-53 (Fig. 5C) from sample M-13680, depth $903.8 \mathrm{~m}$.

Type locality. Baldone drill core, central Latvia.

Type horizon. Baldone Formation, Kunda Regional Stage, lower Darriwilian.

Material. 32 specimens from the Baldone Formation, samples M-13680 and M-13682.

Diagnosis. Small Sphaerochitina? with a long and cylindrical neck and a nearly spherical chamber carrying a flat base with a rounded margin.

Description. Vesicle very small, ranging from 78 to $114 \mu \mathrm{m}$ in length (Table 4). Neck cylindrical, with a slightly flaring collar and taking about half of the vesicle length. Flexure distinct, shoulder not developed. Chamber

Table 4. Dimensions of six three-dimensionally preserved specimens of Sphaerochitina? latviensis sp. nov. $\mathrm{L}=$ vesicle length, $\mathrm{Ln}=$ neck length, $\mathrm{Dp}=$ chamber diameter, $\mathrm{Dpn}=$ neck diameter. Asterisk marks the application of the correction factors of 0.8 and 0.7 to the chamber and neck, respectively

\begin{tabular}{|c|c|c|c|c|c|c|c|c|c|}
\hline \multirow[t]{2}{*}{$n=6$} & L & $\mathrm{Ln}$ & $\mathrm{Dp}$ & $\mathrm{Dp} *$ & Dpn & Dpn* & \multirow[t]{2}{*}{ L/Dp* } & \multirow[t]{2}{*}{$\mathrm{Ln} / \mathrm{L}$} & \multirow[t]{2}{*}{$\mathrm{Dpn} * / \mathrm{Dp} *$} \\
\hline & \multicolumn{6}{|c|}{$\mu \mathrm{m}$} & & & \\
\hline Minimum & 78 & 32 & 49 & 49 & 30 & 30 & 1.55 & 0.40 & 0.59 \\
\hline Maximum & 114 & 50 & 56 & 56 & 36 & 36 & 2.09 & 0.53 & 0.69 \\
\hline Average & 93 & 40 & 52 & 52 & 33 & 33 & 1.77 & 0.44 & 0.63 \\
\hline Holotype & 86 & 35 & 49 & 49 & 30 & 30 & 1.73 & 0.41 & 0.62 \\
\hline
\end{tabular}


Table 5. Dimensions of Bursachitina baldonia sp. nov. based on seven flattened specimens. $\mathrm{L}=$ vesicle length, $\mathrm{Dp}=$ chamber diameter, $\mathrm{Da}=$ aperture diameter. Asterisk marks the application of the correction factors of 0.8 and 0.7 to the chamber and aperture, respectively

\begin{tabular}{l|c|r|c|c|c|c|c}
\hline \multicolumn{1}{c|}{$n=7$} & $\mathrm{~L}$ & $\mathrm{Dp}$ & $\mathrm{Dp}$ & $\mathrm{Da}$ & $\mathrm{Da}^{*}$ & $\mathrm{~L} / \mathrm{Dp}^{*}$ & Da*/Dp* \\
\cline { 2 - 5 } & \multicolumn{7}{|c|}{$\mu \mathrm{m}$} \\
Minimum & 100 & 92 & 73 & 52 & 36 & 1.29 & 0.48 \\
Maximum & 131 & 103 & 82 & 63 & 44 & 1.78 & 0.56 \\
Average & 114 & 98 & 78 & 58 & 40 & 1.47 & 0.51 \\
Holotype & 111 & 100 & 80 & 56 & 40 & 1.38 & 0.49 \\
\hline
\end{tabular}

hemispherical (Fig. 5A, C) to conical (Fig. 5B), base margin rounded, base flat. Maximum diameter near the base margin. Neck diameter is about $2 / 3$ of the chamber diameter. A scar could be present at the apex of the base. Vesicle surface is smooth.

Remarks. The chamber of the holotype (Fig. 5C) is nearly spherical; however, in some other specimens it varies from hemispherical (Fig. 5A) to nearly conical (Fig. 5B) resembling Euconochitina. Thus, the generic assignment to Sphaerochitina must be considered tentative. The vesicle outline and size of $S$.? latviensis resemble those of Sphaerochitina mundana Taugourdeau, 1961 (the latter should be reassigned to Belonechitina mundana (Taugourdeau, 1961) because the surface is covered by small spines according to the diagnostic features). There are similarities also in the shape of the vesicle with that of Linochitina sp. (Nõlvak \& Grahn 1993, pl. 6C, and Nõlvak et al. 2019, fig. 6B); however, the latter has usually a distinct basal margin and a convex base with a mucron.

Occurrence. Baldone Formation, Darriwilian of Latvia.

Order OPERCULATIFERA Eisenack, 1931

Family DESMOCHITINIDAE Eisenack, 1931, emend. Paris, 1981

Subfamily DESMOCHITININAE Paris, 1981

Genus Bursachitina Taugourdeau, 1966, restrict. Paris, 1981

Bursachitina baldonia sp. nov.

Figure 6A-D, G

Etymology. Named after the Baldone drill core.

Holotype. Specimen GIT 854-78 (Fig. 6B) from sample M-13670, depth $927.0 \mathrm{~m}$.

Type locality. Baldone drill core, central Latvia.

Type horizon. Šakyna Formation, Kunda Regional Stage, lower Darriwilian.

Material. 38 specimens from the Šakyna Formation, samples M-13670 to M-13671 and possibly M-13682.
Diagnosis. Small desmochitinid with a conical to subspherical chamber.

Description. Vesicle very small, ranging from 100 to $131 \mu \mathrm{m}$ in length (Table 5). Neither the neck nor flexure is developed (Fig. 6B, D), though sometimes a poorly developed neck-like part could be observed (Fig. 6A, C). Chamber conical (Fig. 6B-D) to subspherical (Fig. 6A), with the corrected ratios of the chamber diameter to vesicle length from 0.66 to 0.77 . The aperture diameter after correction is about half the chamber diameter. The base has a rounded margin. The vesicle surface is smooth.

Remarks. Bursachitina baldonia is distinguished within the assemblage by its small conical to subspherical vesicle without a neck and collar. It is most similar to the lower Silurian Bursachitina (cf.) nana from the Baltic region (e.g. Loydell et al. 2003, fig. 16ah; Männik et al. 2015, fig. 6ac), being, however, slightly more rounded. According to Paris et al. (1999), Bursachitina is common in the Silurian and Devonian strata, but only questionably identified from the Ordovician so far. More recently, however, Bursachitina has been identified from the upper Floian of South China (e.g. Liang et al. 2020b, fig. 4A, B). The occurrence of B. baldonia in the Darriwilian is thus not surprising but further analysis is required to ascertain its affinity with Chinese Lower Ordovician and Baltic Silurian material.

Occurrence. Šakyna Formation, Darriwilian of Latvia.

\section{CONCLUSIONS}

In this paper, a Floian to early Darriwilian chitinozoan collection from Latvia, characteristic of the deeper shelf part of the Baltoscandian Basin, is described for the first time. The studied assemblage from the Baldone drill core contains altogether 35 species, with up to 13 species per sample (19 when considering range-through data). It is broadly similar to the previously known chitinozoan assemblages from northern and central Estonia and Sweden. However, four new species are described, and 
four species are identified from the Baltic region for the first time. In particular, the assemblage of the Šakyna Formation is distinct in containing new species, the youngest occurrence of the genus Eremochitina and the oldest occurrence of Bursachitina in Baltica. The new data indicate an overall higher regional diversity of chitinozoans in the early Darriwilian than previous estimates, and suggest biogeographic ties with other palaeocontinents, notably Laurentia and South China. Biostratigraphically important species like Conochitina raymondii, Cyathochitina regnelli and Tanuchitina granbyensis help to constrain the age of the studied succession, but additional deeper shelf sections need to be studied in order to enhance the biostratigraphic utility of chitinozoans through the Öland Regional Series.

Acknowledgements. We are grateful to Mats E. Eriksson and an anonymous reviewer for their constructive questions, suggestions and corrections that helped to improve the manuscript. This study was supported by the Estonian Research Council (grants PRG836 and MOBJD62) and the National Natural Science Foundation of China (grant 41972015). It is a contribution to the IGCP Project 735 'Rocks and the Rise of Ordovician Life'. The publication costs of this article were covered by the Estonian Academy of Sciences.

\section{REFERENCES}

Achab, A. 1980. Chitinozoaires de l'Arenig inférieur de la Formation de Lévis (Québec, Canada). Review of Palaeobotany and Palynology, 31, 219-239.

Achab, A. 1986. Assemblages de chitinozoaires dans l'Ordovicien inférieur de l'est du Canada. Canadian Journal of Earth Sciences, 23, 682-695.

Achab, A. 1989. Ordovician chitinozoan zonation of Quebec and western Newfoundland. Journal of Paleontology, 63, 1424.

Achab, A. \& Maletz, J. 2021. The age of the Euconochitina symmetrica Zone and implication for Lower Ordovician chitinozoan and graptolite zonations of Laurentia. Review of Palaeobotany and Palynology, 295, 104508.

Achab, A. \& Paris, F. 2007. The Ordovician chitinozoan biodiversification and its leading factors. Palaeogeography, Palaeoclimatology, Palaeoecology, 245, 5-19.

Ainsaar, L., Tinn, O., Dronov, A., Kiipli, E., Radzevičius, S. \& Meidla, T. 2020. Stratigraphy and facies differences of the Middle Darriwilian Isotopic Carbon Excursion (MDICE) in Baltoscandia. Estonian Journal of Earth Sciences, 69, 214222.

Aldridge, R. J. \& Armstrong, H. A. 1981. Spherical phosphatic microfossils from the Silurian of North Greenland. Nature, 292, 531-533.

Amberg, C. E., Vandenbroucke, T. R., Molyneux, S. G. \& Servais, T. 2017. Chitinozoans from the upper Tremadocian (Lower Ordovician) Watch Hill Formation of the Lake District, northern England. Palynology, 41, 23-30.
Asselin, E., Achab, A. \& Soufiane, A. 2004. Biostratigraphic significance of lower Paleozoic microfaunas from eastern Canada. Canadian Journal of Earth Sciences, 41, 489-505.

Benoit, A. \& Taugourdeau, P. 1961. Sur quelques Chitinozoaires de l'Ordovicien du Sahara. Revue de l'Institut Français du Pétrole, 16, 1403-1421.

Bergström, S. M., Chen, X., Gutiérrez-Marco, J. C. \& Dronov, A. 2009. The new chronostratigraphic classification of the Ordovician System and its relations to major regional series and stages and to $\delta^{13} \mathrm{C}$ chemostratigraphy. Lethaia, 42, 97-107.

Bergström, S. M., Calner, M., Lehnert, O. \& Noor, A. 2011. A new upper Middle Ordovician-Lower Silurian drillcore standard succession from Borenshult in Östergötland, southern Sweden: 1. Stratigraphical review with regional comparisons. GFF, 133, 149-171.

Bockelie, T. G. 1980. Early Ordovician Chitinozoa from Spitzbergen. Palynology, 4, 1-14.

Chen, X. H., Paris, F., Wang, X. F. \& Zhang, M. 2009. Early and Middle Ordovician chitinozoans from the Dapingian type sections, Yichang area, China. Review of Palaeobotany and Palynology, 153, 310-330.

Cocks, L. R. M. \& Torsvik, T. H. 2005. Baltica from the late Precambrian to mid-Palaeozoic times: the gain and loss of a terrane's identity. Earth-Science Reviews, 72, 39-66.

Cocks, L. R. M. \& Torsvik, T. H. 2021. Ordovician palaeogeography and climate change. Gondwana Research, 100, 53-72.

Combaz, A. \& Peniguel, G. 1972. Étude palynostratigraphique de l'Ordovicien dans quelques sondages du Bassin de Canning (Australie Occidentale). Bulletin du Centre de Recherches Pau-SNPA, 6, 121-167.

de la Puente, G. S. \& Rubinstein, C. V. 2013. Ordovician chitinozoans and marine phytoplankton of the Central Andean Basin, northwestern Argentina: A biostratigraphic and paleobiogeographic approach. Review of Palaeobotany and Palynology, 198, 14-26.

Eisenack, A. 1931. Neue Mikrofossilien des baltischen Silurs. I. Paläontologische Zeitschrift, 13, 74-118.

Eisenack, A. 1955. Neue Chitinozoen aus dem Silur des Baltikums und dem Devon der Eifel. Senckenbergiana lethaea, 36, 311-319.

Eisenack, A. 1959. Neotypen baltischer Silur-Chitinozoen und neue Arten. Neues Jahrbuch für Geologie und Paläontologie, Abhandlungen, 108, 1-20.

Eisenack, A. 1962. Neotypen baltischer Silur-Chitinozoen und neue Arten. Neues Jahrbuch für Geologie und Paläontologie, Abhandlungen, 114, 291-316.

Eisenack, A. 1972. Beiträge zur Chitinozoen-Forschung. Palaeontographica, Abt A, 140, 117-130.

Eisenack, A. 1976. Mikrofossilien aus dem Vaginatenkalk von Hälludden, Öland. Palaeontographica, Abt. A, 154, 181-203.

Finger, K. L. 1982. Lagenochitina cornbazi, a new name for Lagenochitina tumida Combaz and Péniguel, 1972. Journal of Paleontology, 56, 1488-1489.

Geng, L. Y., Wang, Y., Cai, X. Y. \& Tang, P. 2000. Chitinozoan biostratigraphy in China. In Palynofloras and Palynomorphs of China, pp. 209-241. Press of University of Science and Technology of China.

Goldman, D., Leslie, S. A., Nõlvak, J., Young, S., Bergström, S. M. $\&$ Huff, W. D. 2007. The global stratotype section and point 
(GSSP) for the base of the Katian Stage of the Upper Ordovician Series at Black Knob Ridge, southeastern Oklahoma, USA. Episodes, 30, 258-270.

Goldman, D., Nõlvak, J. \& Maletz, J. 2015. Middle to Late Ordovician graptolite and chitinozoan biostratigraphy of the Kandava-25 drill core in western Latvia. GFF, 137, 197-211.

Grahn, Y. 1980. Early Ordovician Chitinozoa from Öland. Sveriges Geologiska Undersökning, Ser. C, 775, 1-41.

Grahn, Y. 1982a. Caradocian and Ashgillian Chitinozoa from the subsurface of Gotland. Sveriges Geologiska Undersökning, Ser. $C, \mathbf{7 7 8}, 1-66$.

Grahn, Y. 1982b. Chitinozoophoran palaeoecology in the Ordovician of Öland. Sveriges Geologiska Undersökning, Ser. C, 792, 3-17.

Grahn, Y. 1984. Ordovician chitinozoa from Tallinn, northern Estonia. Review of Palaeobotany and Palynology, 43, 5-31.

Grahn, Y. \& Nõlvak, J. 2007a. Ordovician Chitinozoa and biostratigraphy from Skåne and Bornholm, southernmost Scandinavia - an overview and update. Bulletin of Geosciences, 82, 11-26.

Grahn, Y. \& Nõlvak, J. 2007b. Remarks on older Ordovician Chitinozoa and biostratigraphy of the Oslo Region, southern Norway. GFF, 129, 101-106.

Grahn, Y. \& Nõlvak, J. 2010. Swedish Ordovician Chitinozoa and biostratigraphy: a review and new data: Palaeontographica Abt B, 283, 5-71.

Grahn, Y. \& Paris, F. 2011. Emergence, biodiversification and extinction of the chitinozoan group. Geological Magazine, 148, 226-236.

Grahn, Y., Nõlvak, J. \& Paris, F. 1996. Precise chitinozoan dating of Ordovician impact events in Baltoscandia. Journal of Micropalaeontology, 15, 21-35.

Hints, O. 2014a. Stop A1: Pakerort and Uuga cliffs on the Pakri Peninsula. In 4th Annual Meeting of IGCP 591, Estonia, 1019 June 2014 (Bauert, H., Hints, O., Meidla, T. \& Männik, P., eds), pp. 133-137. University of Tartu, Tartu.

Hints, O. 2014b. Stop A8: Saka-Ontika Klint. In 4th Annual Meeting of IGCP 591, Estonia, 10-19 June 2014 (Bauert, H., Hints, O., Meidla, T. \& Männik, P., eds), pp. 159-160. University of Tartu, Tartu.

Hints, O. \& Nõlvak, J. 2006. Early Ordovician scolecodonts and chitinozoans from Tallinn, North Estonia. Review of Palaeobotany and Palynology, 139, 189-209.

Hints, O., Delabroye, A., Nõlvak, J., Servais, T., Uutela, A. \& Wallin, A. 2010. Biodiversity patterns of Ordovician marine microphytoplankton from Baltica: Comparison with other fossil groups and sea-level changes. Palaeogeography, Palaeoclimatology, Palaeoecology, 294, 161-173.

Hints, O., Nõlvak, J., Paluveer, L. \& Tammekänd, M. 2011. Conventional and CONOP9 approaches to biodiversity of Baltic Ordovician chitinozoans. Cuadernos del Museo Geominero, 14, 243-249.

Hints, O., Viira, V. \& Nõlvak, J. 2012. Darriwilian (Middle Ordovician) conodont biostratigraphy in NW Estonia. Estonian Journal of Earth Sciences, 61, 210-226.

Hints, O., Martma, T., Männik, P., Nõlvak, J., Põldvere, A., Shen, Y. \& Viira, V. 2014. New data on Ordovician stable isotope record and conodont biostratigraphy from the Viki reference drill core, Saaremaa Island, western Estonia. GFF, 136, 100-104.
Hints, O., Antonovitš, L., Bauert, G., Nestor, V., Nõlvak, J. \& Tammekänd, M. 2018. CHITDB: a database for documenting and analysing diversification of OrdovicianSilurian chitinozoans in the Baltic region. Lethaia, 51, 218227.

Hints, O., Nõlvak, J. \& Liang, Y. 2021. Possible metazoan egg fossils from the Darriwilian (Middle Ordovician) of Baltoscandia. Estonian Journal of Earth Sciences, 70, 240252.

Jaanusson, V. 1976. Faunal dynamics in the Middle Ordovician (Viruan) of Baltoscandia. In The Ordovician System; Proceedings of a Palaeontological Association Symposium, Birmingham, 1974 (Bassett, M. G., ed.), pp. 301-326. University of Wales Press.

Jaanusson, V. 1995. Confacies differentiation and upper Middle Ordovician correlation in the Baltoscandian basin. Proceedings of the Estonian Academy of Science, Geology, 44, 73-86.

Kaljo, D., Nõlvak, J. \& Uutela, A. 1996. More about Ordovician microfossil diversity patterns in the Rapla section, northern Estonia. Proceedings of the Estonian Academy of Sciences, Geology, 45, 131-148.

Laufeld, S. 1967. Caradocian Chitinozoa from Dalarna, Sweden. Geologiska Föreningen i Stockholm Förhandlingar, 89, 275-349.

Liang, Y. \& Tang, P. 2016. Early-Middle Ordovician chitinozoan biostratigraphy of the Upper Yangtze region, South China. Journal of Stratigraphy, 40, 136-150 [in Chinese, with English abstract].

Liang, Y., Servais, T., Tang, P., Liu, J. \& Wang, W. 2017. Tremadocian (Early Ordovician) chitinozoan biostratigraphy of South China: An update. Review of Palaeobotany and Palynology, 247, 149-163.

Liang, Y., Hints, O., Luan, X. C., Tang, P., Nõlvak, J. \& Zhan, R. B. 2018. Lower and Middle Ordovician chitinozoans from Honghuayuan, South China: Biodiversity patterns and response to environmental changes. Palaeogeography, Palaeoclimatology, Palaeoecology, 500, 95-105.

Liang, Y., Bernardo, J., Goldman, D., Nõlvak, J., Tang, P., Wang, W. H. \& Hints, O. 2019. Morphological variation suggests that chitinozoans may be fossils of individual microorganisms rather than metazoan eggs. Proceedings of the Royal Society B, 286, 20191270.

Liang, Y., Hints, O., Tang, P., Cai, C. Y., Goldman, D., Nõlvak, J., Tihelka, E., Pang, K., Bernardo, J. \& Wang, W. H. 2020a. Fossilized reproductive modes reveal a protistan affinity of Chitinozoa. Geology, 48, 1200-1204.

Liang, Y., Wang, G., Servais, T., Wu, R., Nõlvak, J., Hints, O., Wei, X., Gong, F. \& Yan, G. 2020b. Age constraints of the Hungshihyen Formation (Early to Middle Ordovician) on the western margin of the Yangtze Platform, South China: New insights from chitinozoans. Palaeoworld, 29, 66-74.

Liang, Y., Nõlvak, J., Xu, H., Chen, Y. \& Hints, O. 2022. Revision of Ordovician chitinozoan Lagenochitina esthonica sensu lato: morphometrics, biostratigraphy and paleobiogeography. Journal of Paleontology, 96, 46-60.

Lindskog, A., Eriksson, M. E. \& Pettersson, A. M. 2014. The Volkhov-Kunda transition and the base of the Holen 
Limestone at Kinnekulle, Västergötland, Sweden. GFF, 136, 167-171.

Lindskog, A., Costa, M. M., Rasmussen, C., Connelly, J. N. \& Eriksson, M. E. 2017. Refined Ordovician timescale reveals no link between asteroid breakup and biodiversification. Nature Communications, 8, 14066.

Lindskog, A., Eriksson, M. E., Rasmussen, J. A., Dronov, A. \& Rasmussen, C. M. Ø. 2020. Middle Ordovician carbonate facies development, conodont biostratigraphy and faunal diversity patterns at the Lynna River, northwestern Russia. Estonian Journal of Earth Sciences, 69, 37-61.

Löfgren, A., Viira, V. \& Mens, K. 2005. Conodont biostratigraphy and sedimentary history in the upper Tremadoc at Uuga, Cape Pakri, NW Estonia. GFF, 127, 283-293.

Loydell, D. K., Männik, P. \& Nestor, V. 2003. Integrated biostratigraphy of the lower Silurian of the Aizpute-41 core, Latvia. Geological Magazine, 140, 205-229.

Männik, P., Loydell, D. K., Nestor, V. \& Nõlvak, J. 2015. Integrated Upper Ordovician-lower Silurian biostratigraphy of the Grötlingbo-1 core section, Sweden. GFF, 137, 226244.

Männil, R. 1963. The biostratigraphic subdivision of the Ordovician strata in western Latvia. ENSV TA Geoloogia Instituudi uurimused, XIII, 41-74 [in Russian].

Männil, R. 1966. Evolution of the Baltic Basin During the Ordovician. Valgus Publishers, Tallinn, 200 pp. [in Russian, with English summary].

Miller, M. A. 1996. Chapter 11. Chitinozoa. In Palynology: Principles and Applications. 1 (Jansonius, J. \& McGregor, D. C., eds), pp. 307-336. American Association of Stratigraphic Palynologists Foundation.

Modliński, Z., Nõlvak, J. \& Szymanski, B. 2002. Chitinozoan biozonation of the Ordovician succession in the borehole Proniewicze IG 1. Przeglad Geologiczny, 50, 67-74.

Nõlvak, J. 1980. Chitinozoans in biostratigraphy of the northern East Baltic Ashgillian. A preliminary report. Acta Palaeontologica Polonica, 25, 253-260.

Nõlvak, J. 1997. Ordovician. Introduction. In Geology and Mineral Resources of Estonia (Raukas, A. \& Teedumäe, A., eds), pp. 52-55. Estonian Academy Publishers, Tallinn.

Nõlvak, J. 2010. Distribution of Ordovician chitinozoans. In Viki Drill Core (Põldvere, A., ed.), Estonian Geological Sections, $10,17-18$.

Nõlvak, J. \& Grahn, Y. 1993. Ordovician chitinozoan zones from Baltoscandia. Review of Palaeobotany and Palynology, 79, 245-269.

Nõlvak, J., Hints, O. \& Männik, P. 2006. Ordovician timescale in Estonia: recent developments. Proceedings of the Estonian Academy of Sciences, Geology, 55, 95-108.

Nõlvak, J., Liang, Y. \& Hints, O. 2019. Early diversification of Ordovician chitinozoans on Baltica: New data from the Jägala waterfall section, northern Estonia. Palaeogeography, Palaeoclimatology, Palaeoecology, 525, 14-24.

Nowak, H., Servais, T., Pittet, B., Vaucher, R., Akodad, M., Gaines, R. R. \& Vandenbroucke, T. R. A. 2016. Palynomorphs of the Fezouata Shale (Lower Ordovician, Morocco): age and environmental constraints of the Fezouata Biota. Palaeogeography, Palaeoclimatology, Palaeoecology, 460, 62-74.
Obut, A. M. 1973. On the geographic distribution, comparative morphology, ecology, phylogeny and systematic position of chitinozoans. In Environment and Life in the Geological Past (Zhuravleva, J. T., ed.), pp. 72-84 [in Russian].

Obut, O. T. 1995. Novye vidy kitinozoj v ordovike Moskovskoj sineklizy [New species of chitinozoans in the Ordovician of the Moscow Syneclise]. In Geologiya $i$ geokhimiya osadochnykh bassejnov Sibiri [Geology and Geochemistry of Sedimentary Basins of Siberia], pp. 47-53. Novosibirsk [in Russian].

Paris, F. 1981. Les Chitinozoaires dans le Paléozoïque de sudouest de l'Europe: cadre géologique, étude systématique, biostratigraphie. Société géologique et minéralogique de Bretagne, Rennes, 496 pp.

Paris, F. \& Nõlvak, J. 1999. Biological interpretation and paleobiodiversity of a cryptic fossil group: the "chitinozoan animal". Geobios, 32, 315-324.

Paris, F., Grahn, Y., Nestor, V. \& Lakova, I. 1999. A revised chitinozoan classification. Journal of Paleontology, 73, 549-570.

Paris, F., Achab, A., Asselin, E., Chen, X. H., Grahn, Y., Nõlvak, J., Obut, O., Samuelsson, J., Sennikov, N. \& Vecoli, M. 2004. Chitinozoans. In The Great Ordovician Biodiversification Event (Webby, B., Droser, M., Paris, F. \& Percival, I., eds), pp. 294-311. Columbia University Press.

Paris, F., Miller, M. A. \& Zalasiewicz, J. 2015. Early Silurian chitinozoans from the Qusaiba type area, north Central Saudi Arabia. Review of Palaeobotany and Palynology, 212, 127-186.

Põldsaar, K., Ainsaar, L., Nemliher, R., Tinn, O. \& Stinkulis, G. 2019. A siliciclastic shallow-marine turbidite on the carbonate shelf of the Ordovician Baltoscandian palaeobasin. Estonian Journal of Earth Sciences, 68, 1-14.

Põldvere, A., Meidla, T., Bauert, G., Bauert, H. \& Stouge, S. 1998. Ordovician. In Tartu (453) drillcore (Põldvere, A., ed.), Estonian Geological Sections, 1, 11-17.

Quintavalle, M. \& Playford, G. 2006. Palynostratigraphy of Ordovician strata, Canning Basin, Western Australia. Part Two: chitinozoans and biostratigraphy. Palaeontographica Abt A, 275, 89-131.

Saadre, T., Einasto, R., Nõlvak, J. \& Stouge, S. 2004. Ordovician stratigraphy of the Kovel-1 well (Volkhov-Haljala) in the Volynia region, northwestern Ukraine. Bulletin of the Geological Society of Denmark, 51, 47-69.

Schallreuter, R. 1981. Chitinozoen aus dem Sularpschiefer (Mittelordoviz) von Schonen (Schweden). Palaeontographica Abt B, 178, 89-142.

Servais, T., Achab, A. \& Asselin, E. 2013. Eighty years of chitinozoan research: From Alfred Eisenack to Florentin Paris. Review of Palaeobotany and Palynology, 197, 205-217.

Stauffer, C. R. 1933. Middle Ordovician Polychaeta from Minnesota. Bulletin of the Geological Society of America, 44, 1173-1218.

Tammekänd, M., Hints, O. \& Nõlvak, J. 2010. Chitinozoan dynamics and biostratigraphy in the Väo Formation (Darriwilian) of the Uuga Cliff, Pakri Peninsula, NW Estonia. Estonian Journal of Earth Sciences, 59, 25-37.

Tang, P., Paris, F., Geng, L.-Y. \& Zhu, H.-C. 2007. Chitinozoan biostratigraphy across the base of Darriwilian Stage from the type area in Eastern China. Review of Palaeobotany and Palynology, 146, 74-101. 
Taugourdeau, P. 1961. Chitinozoaires du Silurien d'Aquitaine. Revue de Micropaleontologie, 4, 135-154.

Taugourdeau, P. 1966. Les Chitinozoaires, techniques d'études, morphologie et classification. Mémoires de la Société Géologique de France (Nouvelle Série), 104, 1-64.

Taugourdeau, P. \& de Jekhowsky, B. 1960. Répartition et description des Chitinozoaires Siluro-Dévoniens de quelques sondages de la C.R.E.P.S., de la C.F.P.A. et de la S.N. REPAL au Sahara. Revue de l'Institut Français du Pétrole, 15, 1199-1260.

Ulst, R., Gailite, L. \& Yakovleva, V. 1982. Ordovik Latvii [Ordovician of Latvia]. Zinatne, Riga, 294 pp. [in Russian].

Viira, V. 2011. Lower and Middle Ordovician conodonts from subsurface of SE Estonia and adjacent Russia. Estonian Journal of Earth Sciences, 60, 1-21.

Wang, W. H., Feng, H. Z., Vandenbroucke, T. R. A., Li, L. X. \& Verniers, J. 2013. Chitinozoans from the Tremadocian graptolite shales of the Jiangnan Slope in South China. Review of Palaeobotany and Palynology, 198, 45-61.

Wang, W. H., Liang, Y., Lyu, Q., Hints, O., Chen, S. \& Nõlvak, J. 2021. Chitinozoans with "skirt": Ultrastructure and palaeo- ecological implications of carina in Cyathochitina Eisenack, 1955. Palaeogeography, Palaeoclimatology, Palaeoecology, 570, 110348.

Wang, X. F. \& Chen, X. H. 1994. Lower Ordovician Chitinozoa biostratigraphy and paleogeography of Upper Yangtze region. Acta Palaeontologica Sinica, 33, 720-738 [in Chinese, with English abstract].

Wrona, R. 1980. Microarchitecture of the chitinozoan vesicles and its paleobiological significance. Acta Palaeontologica Polonica, 25, 123-163.

Wu, R. C., Calner, M. \& Lehnert, O. 2017. Integrated conodont biostratigraphy and carbon isotope chemostratigraphy in the Lower-Middle Ordovician of southern Sweden reveals a complete record of the MDICE. Geological Magazine, 154, 334-353.

Zhang, M. \& Chen, X. H. 2009. Early Ordovician chitinozoans from the Fenghsiang and Hunghuayuan formations in Chenjiahe of Yichang, Hubei. Journal of Stratigraphy, 4, 425-431 [in Chinese, with English abstract].

\title{
Vara- ja Kesk-Ordoviitsiumi kitiinikud Kesk-Lätis Baldone puuraugus
}

\author{
Jaak Nõlvak, Yan Liang ja Olle Hints
}

Vara- ja Kesk-Ordoviitsiumi kitiinikud on Baltoskandias võrdlemisi halvasti tuntud. See on vähendanud nende biostratigraafilist väärtust ning raskendanud arengu ja elurikkuse mustrite rekonstrueerimist. Käesolevas artiklis on dokumenteeritud Flo ja Darriwili lademe kitiinikute levikut Baldone puursüdamikus Kesk-Lätis, piirkonnas, kust varasem andmestik praktiliselt puudub. Baldone puuraugu Alam- ja alam Kesk-Ordoviitsiumi kihtide läbilõige on Baltoskandia idaosas üks paksemaid ulatudes 85 meetrini, mida esindavad valdavalt punavärvilised ja harvem hallid merglid ning lubjakivid. 20 uuritud proovist tuvastati kokku 13 perekonda ja 35 liiki kitiinikuid. Vanim kitiinikuid sisaldav proov Flo lademe alaosast (Hunnebergi regionaal-lade) esindab üht vanimat kitiinikute kooslust Baltoskandias. Flo lademe ülaosa ja Dapingi lademe (Billingeni ja Volhovi regionaal-lade) punavärvilised kihid kitiinikuid ei sisalda, kuid Darriwili lademesse kuuluvad Šakyna ja Baldone kihistu kivimid (Kunda regionaal-lade) sisaldavad rikkalikku ja hästi säilinud kitiinikute kooslust. Läbivat andmestikku arvestav taksonoomiline mitmekesisus ulatub neis kihtides 19 liigini proovi kohta. Baldone puuraugu andmestik annab uusi teadmisi Eestis ja Rootsis Kunda regionaal-lademele iseloomuliku biotsonaalse liigi Cyathochitina regnelli leviku kohta. Samuti leiti mitmeid teisi biostratigraafiliselt olulisi liike perekondadest Cyathochitina, Conochitina ja Lagenochitina, mis on tüüpilised teistele regioonidele. Need liigid viitavad ühtlasi Baltika paleokontinendi biogeograafilistele seostele teiste piirkondadega Darriwili eal. Rikkaliku materjali baasil oli võimalik täiendada kitiinikute taksonoomilise mitmekesisuse hinnanguid Baltoskandias ning kirjeldada neli uut kitiinikuliiki: Bursachitina baldonia, Conochitina ulsti, Eremochitina? procera ja Sphaerochitina? latviensis. 